\title{
PARADOX BETWEEN THE SUTAINABLE DEVELOPMENT AND CORPORATE PERFORMANCE
}

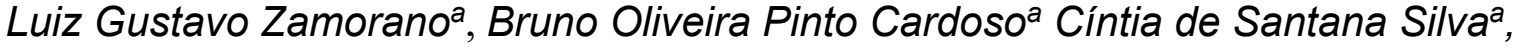 \\ Mário Joel Ramos Júniora , Paulo Vitor Sampaio Vergne de Abreu ${ }^{a}$, Dr. Renelson

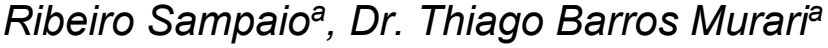

a, Senai Cimatec, Brazil

\begin{abstract}
The fast growth of global economy is causing many issues in the socialenvironmental field. In an attempt to protect future generations, new rules and sustainability regulations were deployed however its becoming a significant paradox to corporation's financial healthy. Using a systematic bibliography revision method about most relevant work in this field, this paper has the objective to evaluate the correlation between sustainable development and corporative performance despite the industrial and economic challenges in the capitalism's dynamic post COVID-19. Is important to note that even tough sustainability can increase production costs, in the long-term can bring prosperity due to its sustainable image and purpose. In addition to that, COVID19 's pandemic is changing completely the market dynamics and economic relationship
\end{abstract}

Keywords: Paradox; Sustainable; Corporate; Infrastructure; Pandemic.

\section{PARADOXO ENTRE O DESENVOLVIMENTO SUSTENTÁVEL E O DESEMPENHO CORPORATIVO}

Resumo: O crescimento acelerado da economia mundial trouxe consigo problemas no âmbito socio-ambiental. Preocupando-se com o impacto para as gerações futuras, medidas de controle e de responsabilidade vem sendo implantadas mas se mostranto um paradoxo de prosperidade para as grandes coorporações. Utilizando como metodologia a revisão sistemática da literatura e dos principais trabalhos sobre o tema, este artigo tem o objetivo avaliar a correlação entre o desenvolvimento sustentável e o desempenho corporativo frente aos desafios industriais e econômicos que surgem com esta nova dinâmica capitalista pós COVID-19. Observa-se que embora a sustenbilidade possa onerar os custos de produção, no longo prazo pode trazer prosperidade associada a esta imagem. Como fator relevante adicional, a pandemia do COVID-19 alterou completamente a dinâmica de mercado e relações econômicas

Palavras-Chave: Paradoxo; Sustentável; Coorporativo; Infra-Estrutura; Pandemia 


\section{INTRODUCTION}

The Stockholm Conference was the first global conference about environment. UN (1972) and set an action plan for The Environment, which was a combination of 109 recommendations to be implemented internationally. The second global conference about environment was the Union Nation Conference - Eco 92. UN (1992) which presented the 21 Agenda - document developed to set the systematic parameters for a sustainable development. UN (1998) highlights the fact that Kyoto's Protocol was an international agreement where industrialized countries made a commitment to reduce greenhouse gas emissions by $5 \%$ between 2008 and 2012. As described by UN (2015), Paris's agreement main objective was to strengthen the global actions against climate change's threat and global warming. Government around the world got engaged to develop their own agenda, using National Contribution Determinations, NDC, as reference.

According to UNEP (2011)'s evaluation, national governments have a key role to play promoting sustainable development, mainly thru adoption of policies and measures to motivate sustainable initiatives, which guarantee environment preservation and protects future generations about significant environmental risks

With the constant industrialization growth, the environmental concerns become more prominent. (Gupta \& Gupta, 2020) pointed that Asia-Pacific markets witnessed a series of extreme climate changes in the last decades. An extreme 2008 winter in China, flooding in China, Taiwan and Hong Kong in 2009, the drought at northeast Australia and a cyclone at Miamar in 2008 are a few examples. The climate changes subject has become a significant source of risks and challenges for all governments around the world. Zhang et. al. (2018) highlights that corporations have an important role promoting economic development in a given country. Nevertheless, financial heathy is crucial for a corporation existence and development, the environmental benefits are becoming more important for the long-term enterprise growth. The paradox is defined due to the relation of two contradictory elements, however deeply interconnected (Gao et al., 2019).

It's still too early to understand the damage this wave of new coronavirus will cause in the globe, however occurrence of other epidemies along history leave us with one certainty: the world will be a different place when the virus's wave flow back (Maranhão apud Gonzatto et al., 2020). A significant number of corporations already started to change however the level and speed of this changes can't be precisely predicted. In the other hand, associated with the need of transformation, old issues become more evident. It's the case of lack of infrastructure, excessive bureaucracy and economic instability in Brazil. In this perspective, innumerous economic and industrial challenges raise as consequence of the global scenario. Structural transformation in some sectors are them required for alignment in this context.

The objective of this paper is to evaluate the correlation between the sustainable development and the corporate performance front of the industrial and economic challenges in the new capitalist's dynamic post COVID-19, like infrastructure, debureaucratization and economic stability in Brazil. Analysis was done evaluating studies published since 2018. 
This paper is organized in four sections: besides this introduction, section 2 describes methodology used, section 3 presents results and finally, in the section 4 , conclusion.

\section{METHODOLOGY}

The study was conducted thru a systematic literature revision and Science Direct was the repository used as database to search papers related to this subject. The central question was:

a) There is a positive or negative correlation between the sustainable development and corporative performance?

Main descriptors used were: "Sustainable Development" and "Corporate Performance". In addition to that, inclusion criteria defined during the publication search were: Content relevance in relation to subject covered in this paper, revision papers or research, written in English or Portuguese. Search was not limited for a specific period and papers published in languages different than specified were not considered.

After search was completed, a total of 152 papers related to this paper subject were found. 10 papers with more relevance were selected and evaluated by authors, to compose this systematic revision, after reading of title and abstract.

\section{RESULTS AND DISCUSSION}

\subsection{Impact of "Green production" in the Corporative Finance}

Arouri et al. (2012) informs that due to environmental restrictions, enterprises have extra costs (capital investment for green production and taxes for excessive emissions) which induces increase of operational costs, and consequently, reduces productivity and profitability. Due to restrictions related to usage of polluted energy, some companies cannot adapt their production lines and, consequently, are forced to pay excessive high taxes due to emissions

Zhang et al. (2018) highlights that, when corporations invest in management and controls of pollution, the investment in production is reduced, causing drop of production and an adverse impact of corporative performance

Shadbegian \& Gray (2005) examined the impact of environmental regulation above productivity in paper factories, oil refinery and steel mills and concluded that corporative productivity reduces with the increase level of environmental restriction.

Arouri et al. (2012) point that, when governments select more severe regulations policy, production costs increase and make companies with more intense pollution less competitive in international markets, therefore, affecting overall development strategy for markets in question. Besides to that, the differences in environmental standards between countries, can induce relocation of industries from 
countries with more strict regulations to countries with more soft standards - the effected "pollution heaven".

When analyzing influence of applied measures for emission reduction thru use of clean energy and installation of environmentally friendly equipment at energy sector in the United States, Granderson \& Prior (2013) found that those measures increased operational costs and reduced productivity.

Studies reviewed in this section shown that production adjustment, to comply with environmental standards, have direct impact in corporate finance. Companies resources are limited and, to maximize value to the shareholders, managers have to search for strategies which increase profitability and guarantee profit increase overtime. Changes in law and regulations affects enterprises, creating threats or opportunities.

Government decision to adopt more strict policies to comply with international agreements and minimize environmental impact can cause migration of corporations to other countries were environmental policies are more flexible. When taken these decisions, managers avoid expending with acquisition and adjustment of factories, processes, machinery and human resources and can allocate those resources in other activities which will add more value to the company, for example entering new markets for potential business expansion.

\subsection{Corporate performance beyond Finances}

The theory of stakeholders explains that enterprises, to be successful, share information and align expectations of its main players, like costumers, government and employees. (Gupta \& Gupta, 2020) adds that all stakeholders, including investors in above definition, expect that companies take appropriate environmental actions in all operating aspects.

The competition is defined, in the business world, in a process that includes rivalry between organizations, this one also covering market context, and insertion of new areas were return is apparently attractive. As observed in the Duratex's sustainable manager interview, leader in wood panel production in the Brazilian market. In Europe, there are restrictions to prohibit installation of companies with high formol-urea emission's rate, natural derivative of the production process in companies from this field (Sambiase et al., 2013).

According to (Zago et al., 2018), companies that maintain values and an ideology which respect purpose other reasons to be, besides financial results, can get better profitability than enterprises that only values profit maximization.

According to study conducted by (Zago et al., 2018) it could not be identified statistically relevant changes, in short term, between negotiated volume and stock prices before and after inclusion of Dow Jones sustainability index, showing an insignificant relation between socioenvironmental and financial performance. In the (Cristófalo et al., 2016) research, conducted to evaluate performance of corporations that are part of the Enterprise Sustainability index from BM\&F Bovespa (ESI) in relation to companies from the same segment but that are not included on ESI, from period between 2006 to 2014 , better performance for companies from the financial and 
petrochemical sector could be noticed and unsatisfactory performance for companies from the electric, paper and cellulose segments.

Studies analyzed shown that even though its complex to evaluate relation between compliance with sustainable development practices and corporate performance, it's possible to identify long term benefits, for companies which target to expand their markets, which suffer great image influence from interested parties or wish to stablish relations with organizations which follow policies of environmental preservation.

\subsection{Industrial and Economic challenges in Brazil facing Pandemy Scenario}

It's evident that the COVID-19 pandemic is changing the way costumers interacts with companies and in a certain way, pressing corporations to reinvent themselves to fulfil new demands, in the most different ways. One of the consequences of social distancing is the increase of remote work or Home office, innumerous companies are adopting this alternative. According to (Informe et al., 2020), home office become viable up to this moment where your generalization and routinization, requiring significant changes in the work environment, besides companies' investments in digital platforms and new solutions related to workday.

Equally, financial institutions are keeping $30 \%$ to $40 \%$ of its workforce in this modality of work, companies are also verifying possibility to expand their business as in the online entertainment market, broad band service provider, games industry, and others are temporally adapting to overcome the crisis like malls and drive-in movie theaters. In this context, according to Schumpeter (1982), crises are required to purge the market, its upon them that new technologies emerge as waves, keeping companies more efficient and innovative, leaving behind the less capable ones.

In this perspective, thru this change, the need for public policies become more evident as part of the solution for old structural problems in Brazil, like: Roads, Ports, Airports, Railway and Fluvial transport. With the exponential growth of companie's platform like Amazon and Magazine Luiza, thru on-line sales, increases also the need for logistic infrastructure. The effects in this segment, indicates that sustainability rely on significant infrastructure investments in the short and also long term. The deficit in proper infrastructure categorizes as an obstacle for the growth of this companies and certainty it's the main challenge for the corporations where survival depends on these channels.

Other significant challenge is the economic stability. Since beginning of COVI19 crises the variation of national currency value in comparison mainly to Dollar and Euro jeopardizes companies which imports raw material to produce consumer goods as well companies that were finished god's importer. All of that in conjunction with a significant interest rate reduction (SELIC) its causing and evasion of foreign capital. This volatility in the Economy don't provide required safe and stable environment so foreign investors have trust to invest in the country.

Lastly but not less important is the de-Bureaucratization. According to the Brazilian Service for Support of Micro and Small Companies (SEBRAE), timing required to open a new company in Brazil can vary from 5 to 30 days, however, after this period is still required to run a proper registration in the Tow Hall, State, IRS and Pension, besides Environmental Secretary and auditing agencies for companies that 
due to segment, requires other agencies or regulatory entities. In Portugal, for example, the same process of opening a new company can be done in only one (01) hour, and the requestor leaves the Office with all the documentation to start operation of its new company (Ferreira et al., 2007).

\section{CONCLUSION}

Papers and studies reviewed confirms that compliance with current sustainability rules and measures can increase significantly the production costs becoming a challenge for competitiveness and profitability for corporations. However, can also be noticed that if you consider long term, the impact of those measures can be positive once associated with an image of care and compliance with regulations that seek well-being and survival of future generations. The coronavirus crisis presents as an additional factor which is changing completely the market's dynamics and the economic relationships. In other hand, highlighting all the infra structure weakness and limitations of Brazilian's economy.

\section{Acknowledgments}

The authors thanks and acknowledges Senai Cimatec University.

\section{REFERENCES}

[1] UNITED NATIONS (UN). Report of the United Nations Conference of the Human Enviroment. Stockholm, 1972. Available at: <http://www.un-documents.net/aconf4814r1.pdf>. Accessed: May 30"th 2020.

[2] UNITED NATIONS (UN). Earth Summit Agenda 21. Rio de Janeiro, 1992. Available at: https://sustainabledevelopment.un.org/index.php?page=view\&nr=23\&type=400\&men $\underline{\mathrm{u}=35}>$. Accessed: May 30 ${ }^{\text {th }}, 2020$.

[3] UNITED NATIONS (UN). Kyoto Protocol Reference Manual. Kyoto, 1998. Available at: $\quad<$ https://unfccc.int/resource/docs/publications/08 unfccc $\mathrm{kp}$ ref manual.pdf>. Accessed: May 30 2020.

[4] UNITED NATIONS (UN). Paris Agreement. Paris, 2015. Available at: $<$ https://unfccc.int/sites/default/files/english paris agreement.pdf $>$. Accessed: May $30^{\text {th }}, 2020$

[5] UNITED NATIONS ENVIRONMENTAL PROGRAMME (UNEP). Towards a green economy: pathways to sustainable development and poverty eradication. 2011. 
Available

at: $<$ https://sustainabledevelopment.un.org/content/documents/126GER synthesis en.p df>

[6] GUPTA, A. K., \& Gupta, N. (2020). Effect of corporate environmental sustainability on dimensions of firm performance - Towards sustainable development: Evidence from India. Journal of Cleaner Production, 253, 119948. Available at: <https://doi.org/10.1016/j.jclepro.2019.119948>

[7] ZHANG, L.; LONG, R; CHEN, H.; HUANG, H. Performance Changes Analysis of Industrial under Energy Constraints. Resources, Conservation \& Recycling. v. 136, p. 248-256. 2018.

[8] GAO, Y., Li, Z., \& Khan, K. (2019). A study on the relationship between paradox cognition, green industrial production, and corporate performance. Sustainability (Switzerland), 11(23). Available at: <https://doi.org/10.3390/su11236588>

${ }^{[9]}$ AROURI, M. E. H.; CAPORALE, G. M.; RAULT, C.; SOVA, R.; SOVA, A. Environmental Regulation and Competitiveness: Evidence from Romania. Ecological Economics. v. 81, p. 130-139. 2012.

[10] SHADBEGIAN, R. J.; GRAY, W.B. Pollution abatement expenditures and plantlevel productivity. A production function approach. Ecological Economics. v. 54, p. 196-208. 2005.

[11] SCHAD, J.; LEWIS, M.W.; RAISCH, S.; SMITH, W.K. Paradox research in management science: Looking back to move forward. Acad. Manag. Ann. 2016, $10,5-64$

[12] GRANDERSON, G.; PRIOR, D. Environmental Externalities and Regulation Constrained Cost Productivity Growth in the U.S. Electric Utility Industry. Journal of Productivity Analysis.

INFORME, E. N. S. P. et al. Covid-19 e avanço tecnológico: nasce um outro mundo do trabalho, avaliam especialistas. 2020.

[13] SAMBIASE, M. F., Franklin, M. A., \& Teixeira, J. A. (2013). Inovação Para O Desenvolvimento Sustentável Como Fator De Competitividade Para As Organizações: Um Estudo De Caso Duratex. Review of Administration and Innovation - RAI, 10(2), 144-168. Available at: <https://doi.org/10.5773/rai.v10i2.878> 
${ }^{[14]}$ ZAGO, A. P. P., Jabbour, C. J. C., \& Bruhn, N. C. P. (2018). Sustentabilidade corporativa e criação de valor: o caso "Dow Jones Sustainability Index." Gestão \& Produção, 25(3), 531-544. Available at: <https://doi.org/10.1590/0104-530x2958-16>

${ }^{[15]}$ CRISTÓFALO, R. G., Akaki, A. S., Abe, T. C., Morano, R. S., \& Miraglia, S. G. E. K. (2016). Sustentabilidade e o mercado financeiro: estudo do desempenho de empresas que compõem o índice de sustentabilidade empresarial (ISE). REGE Revista de Gestão, 23(4), 286-297. Available at: <https://doi.org/10.1016/j.rege.2016.09.001>

[16] SHUMPETER,J.A. Teoria do desenvolvimento econômico: uma investigação sobre lucros, capital, crédito, juro e o ciclo econômico. Serie Econômistas. São Paulo: Abril Cultural. 1982.

${ }^{[17]}$ MARANHÃO, R. A; SENHORAS, E. M. Pacote econômico governamental e o papel do BNDES na guerra contra o novo coronavírus. Boletim de Conjuntura (BOCA), v. 2, n. 4, p. 27-39, 2020.

${ }^{[18]}$ SEBRAE. Passos essenciais para a abertura de uma microempresa. Availabe at:< https://www.sebrae.com.br/sites/PortalSebrae/ufs/go/artigos/passos-essenciais-paraa-abertura-de-umamicroempresa,ac7960ef67f4d610VgnVCM1000004c00210aRCRD> Accessed: May $1^{\text {s }} 2020$ at $19: 58 \mathrm{~h}$.

${ }^{[19]}$ FERREIRA, J. J. M.; MARQUES, C. S. E.; BARBOSA, M. J. Relação entre inovação, capacidade inovadora e desempenho: o caso das empresas da região da beira interior. INMR-Innovation \& Management Review, v. 4, n. 3, p. 117-132, 2007. 